\title{
Correction to: Maternal high fat diet compromises survival and modulates lung development of offspring, and impairs lung function of dams (female mice)
}

\author{
Jordan Smoothy ${ }^{1 \dagger}$, Alexander N. Larcombe ${ }^{1,3 \dagger}$, Emily K. Chivers ${ }^{1}$, Vance B. Matthews ${ }^{2}$ and Shelley Gorman ${ }^{1^{*}}$ (1)
}

\section{Correction to: Respir Res (2019) 20:21} https://doi.org/10.1186/s12931-019-0976-3

Following publication of the original article [1], and upon recent review of the datasets of this manuscript, the authors have discovered some inconsistencies/inaccuracies in the number of animals per group reported in some figure legends (Figs. 3b, 5 and 6).

These are corrected as below:

- Fig. 3b: Fasting insulin levels at 9 (dams fed low fat diet, $\mathrm{n}=14$; or, high fat diet, $\mathrm{n}=10$ ) and 12 weeks (dams fed low fat diet, $\mathrm{n}=12$; or, high fat diet, $\mathrm{n}=12$ ).

- Fig. 5: Lung responsiveness to methacholine (dams fed low fat diet, $\mathrm{n}=12$; or, high fat diet, $\mathrm{n}=11$ ).

- Fig. 6: Serum levels of cytokines or adipokines in offspring born from first (dams fed low fat diet, $\mathrm{n}=5-10$; or, high fat diet, $\mathrm{n}=5-10$ ) or second (dams fed low fat diet, $\mathrm{n}=10-12$; or, high fat diet, $\mathrm{n}=3-5$ ) pregnancies.
The authors apologise for any inconvenience caused.

\author{
Author details \\ ${ }^{1}$ Telethon Kids Institute, University of Western Australia, Northern Entrance \\ Perth Children's Hospital, 15 Hospital Ave, Nedlands, WA 6009, Australia. \\ ${ }^{2}$ School of Biomedical Sciences, University of Western Australia, Perth, Aus- \\ tralia. ${ }^{3}$ School of Public Health, Curtin University, Perth, WA 6845, Australia.
}

Published online: 14 March 2021

Reference

1. Smoothy J, Larcombe AN, Chivers EK, Matthews VB, Gorman S. Maternal high fat diet compromises survival and modulates lung development of offspring, and impairs lung function of dams (female mice). Respir Res. 2019;20:21. https://doi.org/10.1186/s12931-019-0976-3.

\section{Publisher's Note}

Springer Nature remains neutral with regard to jurisdictional claims in published maps and institutional affiliations.

Full list of author information is available at the end of the article to the material. If material is not included in the article's Creative Commons licence and your intended use is not permitted by statutory regulation or exceeds the permitted use, you will need to obtain permission directly from the copyright holder. To view a copy of this licence, visit http://creativecommons.org/licenses/by/4.0/. The Creative Commons Public Domain Dedication waiver (http://creativeco mmons.org/publicdomain/zero/1.0/) applies to the data made available in this article, unless otherwise stated in a credit line to the data. 